\title{
Introduction to the special issue: racialized bordering discourses on European Roma
}

\author{
Nira Yuval-Davis, Georgie Wemyss \& Kathryn Cassidy
}

To cite this article: Nira Yuval-Davis, Georgie Wemyss \& Kathryn Cassidy (2017) Introduction to the special issue: racialized bordering discourses on European Roma, Ethnic and Racial Studies, 40:7, 1047-1057, DOI: 10.1080/01419870.2017.1267382

To link to this article: https://doi.org/10.1080/01419870.2017.1267382
(C) 2016 The Author(s). Published by Informa UK Limited, trading as Taylor \& Francis Group

册 Published online: 06 Jan 2017.

Submit your article to this journal $\widetilde{1}$

\section{Article views: 623}

Q View related articles ¿

View Crossmark data $₫$

4 Citing articles: 1 View citing articles 진 


\title{
Introduction to the special issue: racialized bordering discourses on European Roma
}

\author{
Nira Yuval-Davis ${ }^{a}$, Georgie Wemyss ${ }^{a}$ and Kathryn Cassidy ${ }^{b}$ \\ ${ }^{\mathrm{a} S}$ School of Social Sciences, University of East London, London, UK; ${ }^{\mathrm{b}}$ Department of Geography, \\ Northumbria University, Newcastle-upon-Tyne, UK
}

\begin{abstract}
In the introduction to this special issue, we briefly introduce everyday bordering as the theoretical framing for the papers and explore its relationship to the process of racialization. We introduce our situated intersectional approach to the study of everyday bordering, illustrating the importance of capturing the differentially situated gazes of a range of social actors. We then go on to contextualize the importance of this framing and approach in a wider discussion of Roma in Europe before concluding with a summary of the particular contributions of each of the papers in this special issue to these debates.
\end{abstract}

ARTICLE HISTORY Received 2 November 2015; Accepted 20 September 2016

KEYWORDS Roma; everyday bordering; situated intersectionality; racialization; Europe

\section{Racialized bordering discourses on European Roma}

We are pleased to introduce this special issue of Ethnic and Racial Studies on Roma. Although British and other European racialized discourses have focused primarily on black, southern and increasingly in recent years Muslim minorities, Roma people have continued to be a focus of both racist attitudes and discriminatory policies, in the UK, and in different ways and to varying extents, in other European countries as well as globally. In June 2015, Izsák (2015), the Special Rapporteur for Minority Rights, presented before the Human Rights Council a report on the state of Roma people and "anti-Gypsyism racism" all over the globe. In the announcement about the meeting the Council of Europe defined anti-Gypsyism "as a special kind of racism, an ideology founded on racial supremacy, a form of dehumanization and institutional racism, nurtured by historical discrimination which is 
expressed by violence, hate speech, exploitation, stigmatisation and the most blatant kind of discrimination". ${ }^{1}$

The articles in this issue focus separately and comparatively on several European countries - specifically Hungary, Finland and the UK - and show the racialized constructions of Roma in Europe. The category and boundaries of the Roma (and related communities such as Romani Gypsies and Travellers) have always been contested (Acton 1997; Hancock 2002; Matras 2002) but in recent years we have seen a growing movement of self-determination encompassing them all, at least nominally, in the European Union (EU) and the United Nations (Feys 1997; Klímová-Alexander 2007) under the umbrella term of Roma. We therefore choose to use this label to include all the heterogeneous collectivities discussed in this issue.

Special funds and policies aimed at "integrating" and improving the welfare of Roma people have been developed, but at the same time there has been no significant change in the social processes locating them as "Others". After the collapse of the Soviet Union and the enlargement of the EU, differentiation between "indigenous" and migrant Roma began to emerge within racialized discourses towards Roma. In recent populist debates on East European migration to the UK, for example, there has also been a collapse of the categories "Roma" and "Romanians" with a focus on the actions of the former being used to demonize the latter (see Wemyss and Cassidy 2017).

Most of the scholars writing for this issue have been studying the social, economic and political contexts of Roma populations as part of a large European research project on EUBorderscapes and everyday bordering. ${ }^{2}$ Within the project, the racialized constructions of Roma in media discourses as well as intersectional narratives of everyday social and state borderings, which differentiate, rather than homogenize, different groupings of Roma people, have been the focus of particular strands of the research and analysis.

The first part of this introductory paper focuses on the relationship of racism in general and towards Roma people in particular and intersectional situated constructions of everyday bordering. It then describes in broad brush the history and policies towards Roma people in Europe before introducing the specific articles in this special issue.

\section{Racism and everyday bordering}

Racism, or, rather, the process of racialization, is a discourse and practice which constructs immutable boundaries between collectivities which is used to naturalize fixed hierarchical power relations between them (Anthias and Yuval-Davis 1992; Goldberg 2009; Rattansi 2007; Solomos and Back 1996).

Barth ([1969] 1998) and others following him have argued that it is the existence of ethnic (and racial) boundaries, rather than of any specific "essence" around which these boundaries are constructed that is crucial in 
processes of ethnicization and racialization. Any physical or social signifier, from the colour of the skin to the shape of the elbow to accent or mode of dress, can be used to construct the boundaries, which differentiate between "us" and "them". As the different articles in this issue show, although some of the racialization of the Roma can be seen as linked to the white majority's perceptions of Roma as "dark skinned", ${ }^{3}$ it is mainly linked traditionally to the anti-nomadism of sedentary populations (see e.g. Kabachnik 2010; McVeigh 1997). However, it is important to emphasize that the racialization of Roma continues also when they become sedentary (as a result of a variety of forced and voluntary social practices and policies) but continue to be, to a large extent, a distinct segment of the labour market. In this way, the Roma case echoes Stuart Hall's famous articulation of "class is the modality in which race is lived" (Hall [1978] 1996).

However, to describe contemporary racialization of Roma only as an intersection of "race" and class is an oversimplification. This racialization is closely linked to particular political projects of belonging (Yuval-Davis 2011) in which Roma are constructed and reconstructed as an "other" by continuous processes of everyday bordering. Different political projects of belonging determine where and according to which criteria the boundaries between the collective self and others would be delineated as well as the permeability and solidity of these boundaries. State borders are but one of the technologies used to construct and maintain these boundaries. It is for this reason that contemporary border studies largely refer to "borderings" rather than to borders; seeing them more as a dynamic, shifting and contested social and political spatial processes rather than just territorial lines (Newman 2006; van Houtum and van Naerssen 2002). However, these borders and boundaries are not just top-down macro social and state policies but are present in everyday discourses and practices (Yuval-Davis, Wemyss, and Cassidy 2017) of different social agents, from state functionaries to the media to all other differentially positioned members of society. All of them are engaged in everyday borderings, however, in somewhat different ways and it is for this reason that we need to add the analytical and methodological perspective of situated intersectionality to our study of everyday bordering (Yuval-Davis 2014).

\section{Situated intersectionality}

Intersectionality (e.g. Anthias 2012; Brah and Phoenix 2004; Crenshaw 1989; Hill Collins 1990; Yuval-Davis 2006) has become a major theoretical and methodological perspective in analysing social relations. Indeed, it is argued that it should be adopted as the most valid approach to analysing social stratification, as it is the most comprehensive, complex and nuanced and does not reduce social hierarchical relations into one axis of power, be it class, race or gender. 
The analysis in this special issue follows the specific approach to intersectionality that Yuval-Davis (2014) has named "situated intersectionality". Fundamental to this approach is that intersectionality analysis should be applied to all people and not just to marginalized and racialized women, with whom the rise of Intersectionality theory is historically linked, so as to avoid the risk of exceptionalism and of reifying and essentializing social boundaries.

Epistemologically, intersectionality can be described as a development of feminist standpoint theory, which claims, in somewhat different ways, that it is vital to account for the social positioning of the social agent. Situated gaze, situated knowledge and situated imagination, construct differently the ways we see the world. However, intersectionality theory was interested even more in how the differential situatedness of different social agents relates to the ways they affect and are affected by different social, economic and political projects. In this way it can no doubt be considered as one of the outcomes of the mobilization and proliferation of different identity group struggles for recognition (Taylor 1994). At the same time it can also be seen as a response to some of the problems of identity politics (however important they have been historically in terms of mobilization and exposure of different kinds of oppression), when they conflated social categories and social groupings, individuals and collectives and suppressed the visibility of intra-group power relations and plural voices for the sake of raising the visibility of the social grouping/social category as a whole.

Methodologically, different intersectionality approaches have tended to use what McCall (2005) calls inter- or intra-categorical approaches. By intercategorical approach McCall means focusing on the way the intersection of different social categories, such as race, gender and class affect particular social behaviour or distribution of resources. Intra-categorical studies, on the other hand, are less occupied with the relationships among various social categories but rather problematize the meanings and boundaries of the categories themselves, such as whether black women were included in the category "women" or what are the shifting boundaries of who is considered to be "black" in particular place and time. Our approach to the study of everyday bordering has seen the two as complementary, combining the sensitivity and dynamism of the intra-categorical approach with the socioeconomic perspective of the inter-categorical approach.

Another related issue concerns the importance of differentiating between people's positionings along socio-economic grids of power; their experiential and identificatory perspectives of where they (and others) belong; and their normative value systems (Yuval-Davis 2011, 12-18). These different facets of intersectionality analysis are related to each other but are also irreducible to one other. There is no direct causal relationship between the situatedness of people's gaze and their cognitive, emotional and moral perspectives on life. 
Our team has been able to analyse discourses on everyday bordering from differential situated gazes of different social agents in specific locations in several European countries (e.g. politicians, officials, activists, journalists, local residents of different ethnicities both male and female). As can be seen in the articles in this issue which are concerned with media and contesting discourses, we were able to compare intersectional discourses in relation to different temporal points as well as locational. ${ }^{4}$

\section{Roma in Europe}

There are currently between ten and twelve million ${ }^{5}$ Roma living in Europe. Estimates are variable, in part, because of the contested nature of Roma identity (Nirenberg 2010). The term Roma was first adopted at the inaugural World Romani Congress in London in 1971. We are aware of the fluid and heterogenous nature of such self-identification, and a number of the papers in the special issue (cf. Wemyss and Cassidy) explore the impacts of homogenizing discourses in more detail. We use the term Roma as the endonym from the Romani language, meaning man, rather than other terms in common usage. Originally from the Indian subcontinent, by the time they were first documented in Europe in the fourteenth century, many were already enslaved and/or excluded and marginalized. Other kingdoms across Europe also put to death, expelled or deported (to colonies in the New World) Roma throughout the sixteenth century when the population spread. Whilst some Roma left Europe for North America from the mid1800 s until the outbreak of the Second World War, these flows were relatively modest. In spite of the genocide of Roma under the Nazi regime, Central and Eastern Europe (CEE) was still home to large numbers of Roma at the end of the Second World War, many of whom were subjected to forced assimilation policies within the newly established state socialist regimes. However, as Ruzicka (2012) has argued, it is important that we do not mask the very different experiences of Roma under state socialism. Under socialism, many Roma were resettled in urban centres in the present-day Czech Republic and these populations were more greatly affected by the "crisis" of transition (Sokol 2001) - deindustrialization leading to high unemployment and the regeneration of inner-city areas, which often displaced them from social housing (Keresztely, Scott, and Virag 2017). Recent academic research and human rights monitors have repeatedly identified a significant decline in the socio-economic status of Eastern European Roma/Gypsies, marked by deepening poverty and increasing levels of residential segregation (Barany 2002; Ladányi and Szelényi 2006).

As a result of multiple national projects of belonging across Europe, which seek to exclude Roma, we have seen the emergence of a frame that posits Roma as a people that exist everywhere but belong nowhere. The enactment 
of processes of non-belonging in everyday life results in daily practices of segregation in schooling, housing, and recreation. These processes of everyday bordering in relation to Roma strengthen the majority population's identity (Fidyk 2013). Roma are effectively banished from the imagined communities of European nations (Anderson 1982). The collapse of state socialism led to emerging Roma engagement with political processes in the fledgling democracies, as well as new media and cultural programming in Romani languages. For the Roma, the opening up of channels to the rest of the world presented opportunities for greater international links. However, as Gheorghe (1991) also points out, the removal of state control over the media and other spheres of everyday life in the countries of CEE also led to increases in anti-gypsy discourses and even conflict and attacks on Roma people (Puxon 2000). Many of CEE's estimated eight million Roma sought asylum in the West from the mid-1990s. In spite of NGO reports demonstrating institutionalized racism towards the Roma in the Czech Republic and Slovakia their claims were largely refused on the basis that CEE countries were deemed safe, having the required legislative frameworks to protect minority rights (Guy 2003).

Many more Roma live in Europe than are afforded European citizenship, due to systemic processes of exclusion, which make it difficult for them to meet the requirements of "residency-based" citizenship criteria (Guillem 2011). This is not to support the assumption that Roma or Romani culture is inherently or necessarily nomadic, which has often been central to exclusionary processes (Orta 2010; Pusca 2010). The process of EU accession and enlargement has been one of the key reasons for the emergence of a focus on Roma within EU policy circles. The EU has suggested that they and their members have a "special responsibility towards the Roma". Not only are there many more Roma living in the EU since its eastward expansion, but they have also been highly visible in the East-West migration, which has dominated the continent both prior to and following 2004. The extent of the exclusion of the Roma within the Union led the Commission to adopt a Framework to address the complex issues facing Roma people living in all its member states. However, the EU's framing of their approach to addressing Roma exclusion has been highly problematic. First and foremost, because it bolsters national projects of belonging, which exclude Roma by suggesting they are a "European" people. In addition, the EU's usual process of "norm-spreading", which is used to place pressure on member states to conform to particular ideals and values has been strongly resisted by members because of the differing attitudes towards and existing norms relating to Roma.

Although attempts to create a movement focusing on the rights of Roma have been limited by the heterogeneity of the population (McGarry 2012), there are many initiatives being undertaken by Roma activists across Europe. With its roots in the 1920s and 1930s, calls to recognize the Roma as a nation without a state have increased since 1991 and particularly the late 1990s. 
Initiatives incorporating Roma into mainstream anti-discrimination policies have largely been perceived as inadequate. It is thanks to the sustained efforts of activists in the heart of the EU's bureaucratic institutions in Brussels and elsewhere that the 2011 European Framework for National Roma Integration Strategies was adopted. Whilst organizations such as the European Roma Rights Centre (ERRC) and European Roma Policy Coalition (ERPC) have broadly welcomed some of the EU's initiatives under the Framework to counter exclusion in the spheres of education, health, housing and employment, a joint statement issued in 2011 expressed their disappointment at the EU's failure to address anti-Gypsyism in member states (ERRC/ERPC 2011). Anti-Gypsyism lies at the heart of Roma exclusion and the EU's Framework can hardly be successful whilst it fails to tackle the associated everyday manifestations of this phenomenon, which include intimidation, harassment and violence against Europe's Roma people. The ERRC continues to advocate for the Framework with partners via the EPRC. In addition, the Centre has also worked on growing its grassroots base by training activists across the region. Some of its programmes also focus on training for professionals, for example, in the legal field, as well as briefings for politicians and policy-makers in Brussels and beyond relating to key themes, such as child protection and gender inequalities.

Whilst the EU's efforts in tackling Roma discrimination should be recognized, there is inevitably the question that in Europeanizing the problems of Roma they risk Europeanizing the solution. This can lead to a homogenizing process, in which realities of local and national contexts and relations disappear. As Vermeersch cautions, "even if problems seem similar, causes may vary a lot from place to place and each community might possess different resources and dynamics to deal with these problems" $(2012,15)$. Anti-Gypsyism is by no means the same in every country. Roma as a reified ethnic group play different political and social roles within the domestic and international politics of different states.

We sought contributions, which would highlight the multilevel complexities and diversity of Roma experiences of bordering discourses in different and shifting European contexts, that situated dominant and competing discourses about Roma socially and politically and which sought out Roma voices that challenged their representation.

Within the framework of everyday bordering discussed above several themes run through all papers: the recognition of the long histories of discrimination experienced by Roma communities across Europe; the changing policies of the EU and the tension between the inter-European de-bordering and the selective and restrictive immigration policies introduced as each state reacts to free movement in different ways; the continuing racism experienced by Roma people in their interaction with these bordering technologies; the homogenizing "racialized othering" and construction of Roma as a "criminal 
category" co-existing with the differentiations made between "indigenous" and "migrant" Roma central to the dominant bordering discourses and the heterogeneity, contestations and agency of Roma populations. The first paper engages with political and economic issues that contribute to the production of discourses about Roma through focusing on the increased dependency of Romani organizations and media on non-government donors leading to the marginalization of Roma-led advocacy. Plaut explores how the Romani journalism that now dominates aims at intervening to challenge negative representations of Romani populations and at convincing nonRomani populations that Roma can be included in the wider European identity, drowning out Romani activism and advocacy in Roma-targeted media. The second paper presents an analysis of how discursive and material processes of urban regeneration in Budapest have contributed to the exclusion of long-standing Roma residents. Keresztély, Scott and Virag expose the political intentions of the local government to marginalize Roma families through re drawing social and spatial borders between social and ethnic groups living in the neighbourhood. The third paper extends the analysis beyond the European territorial frame to contrast media discourses in Hungary and Canada about the motivations of and reactions to Hungarian Roma migration to Canada since the 1990s. Varju and Plaut locate the competing discourses in relation to the shifting contexts of the increasingly violent far right politics in Hungary, economic pressures and Canadian migration and welfare policies.

The fourth paper explores how Roma from Eastern Europe who have migrated to Finland navigate a "limboscape" where indirect bordering techniques limit their access to social rights and welfare provision. Tervonen and Enache demonstrate that whilst Roma are clear targets of bordering regimes, such regimes are set up to also deal with other legitimate "unwanted migrants". The government's prioritizing of this "hostile environment" has led to inadequate welfare provision whilst migrant Roma employ diverse economic activities and transnational family networks to challenge the effects of such policies.

A similarly "hostile environment" is the context of the fifth paper that focuses on the bordering experiences of Roma and non-Roma migrants in the UK. Wemyss and Cassidy track the reproduction and contestation of discourses about EU migration associated with the ending of transitional controls showing that as the restrictions on work by A2 citizens in the UK ended, negative discourses about them conflated diverse Roma and non-Roma groups, extending the border further into the lives of both groups in different and complex ways.

The final paper compares how press discourses on the heterogeneous Roma populations of Hungary, Finland and the UK have, since the 1990s, worked as bordering processes differentiating between those who belong to their national collectivities and those who do not. Yuval-Davis, Varju, 
Tervonen, Hakim and Fathi relate national level discourses about Roma to the political positions of the press and the politics of governments in the context of EU expansion, securitization and neo-liberal economies. The extent to which the media give space to Roma voices is shown to be influenced by the historical and political contexts of each state. Despite the more recent inclusion of Roma voices, the authors conclusion that the trajectories of the discourses are towards more racialization, criminalization and exclusion and less collective recognition of Roma populations in the three countries resonates with the findings of the other contributors.

\section{Notes}

1. http://www.ohchr.org/EN/Issues/Minorities/SRMinorities/Pages/ StudyProtectionRoma.aspx.

2. http://www.euborderscapes.eu/; please also see http://www.uel.ac.uk/cmrb/ borderscapes/.

3. Most specifically in the analysis of the "blond Maria" case study in Yuval-Davis et al. (2017).

4. See, for example, Varju and Plaut (2017), Wemyss and Cassidy (2017), and YuvalDavis et al. (2017).

5. Commission Communication COM/2010/0133 of 7th April on the social and economic integration of the Roma in Europe.

\section{Acknowledgements}

Many thanks to all our partners in the EUBORDERSCAPES research project for their intellectual engagement, in particular we are grateful to those who contributed to work package 9 "Borders, Intersectionality and the Everyday".

\section{Disclosure statement}

No potential conflict of interest was reported by the authors.

\section{Funding}

This work was supported by EUBORDERSCAPES [290775] funded by the European Commission under the Seventh Framework Programme [FP7-SSH-2011-1] Area 4.2.1 The evolving concept of borders.

\section{References}

Acton, T. A. 1997. Gypsy Politics and Traveller Identity. Hatfield: University of Hertfordshire Press.

Anderson, B. 1982. Imagined Communities. London: Verso.

Anthias, F. 2012. "Hierarchies of Social Location, Class and Intersectionality: Towards a Translocational Frame." International Sociology 28 (1): 121-138. 
Anthias, F., and N. Yuval-Davis. 1992. Racialized Boundaries: Race, Nation, Gender, Colour and Class and the Anti-racist Struggle. Abingdon: Routledge.

Barany, Z. 2002. The East European Gypsies: Regime Change, Marginality, and Ethnopolitics. Cambridge: Cambridge University Press.

Barth, F. [1969] 1998. Ethnic Groups and Boundaries: The Social Organisation of Cultural Difference. Long Grove, IL: Waveland Press.

Brah, A., and A. Phoenix. 2004. "Ain't I a Woman? Revisiting Intersectionality." Journal of International Women's Studies 5 (3): 75-86.

Crenshaw, K. 1989. Demarginalizing the Intersection of Race and Sex. Chicago: University of Chicago.

European Roma Rights Centre (ERRC)/European Roma Policy Coalition (ERPC) 2011. "EU Framework Weak on Discrimination Against Roma." April 5. Accessed December 18, 2016. http://www.errc.org/article/eu-framework-weak-on-discrimination-againstroma/3824.

European Roma Rights Centre (ERRC)/European Roma Policy Coalition (ERPC) 2011. “EU Framework Weak on Discrimination Against Roma." April 5. Accessed December 18, 2016. http://www.errc.org/article/eu-framework-weak-on-discrimination-againstroma/3824.

Feys, C. 1997. "Towards a New Paradigm of the Nation: The Case of the Roma." Journal of Public and International Affairs-Princeton 8: 1-19.

Fidyk, A. 2013. "Scapegoated in Schools: Reading a Collective Roma Narrative." In Roma Education in Europe: Practices, Policies and Politics, edited by M. Miskovic, 42-58. New York: Routledge.

Gheorghe, N. 1991. "Roma-Gypsy Ethnicity in Eastern Europe." Social Research 58 (4): 829-844.

Goldberg, D. T. 2009. The Threat of Race: Reflections on Racial Neoliberalism. Malden, MA: John Wiley \& Sons.

Guillem, S. M. 2011. "European Identity: Across Which Lines? Defining Europe Through Public Discourses on the Roma." Journal of International and Intercultural Communication 4 (1): 23-41.

Guy, W. 2003. "No Soft Touch': Romani Migration to the UK at the Turn of the Twentyfirst Century." Nationalities Papers 31 (1): 63-79.

Hall, S. [1978] 1996. "Race, Articulation, and Societies Structured in Dominance." In Black British Cultural Studies: A Reader, edited by H. A. Baker Jr., M. Diawara and R. H. Lindeborg, 16-60. Chicago: University of Chicago Press.

Hancock, I. F. 2002. We are the Romani people, 3446. Hatfield: University of Hertfordshire Press.

Hill Collins, P. 1990. Black Feminist Thought. New York: Routledge.

van Houtum, H., and T. van Naerssen. 2002. "Bordering, Ordering and Othering." Tijdschrift voor economische en sociale geografie 93 (2): 125-136.

Izsák, R. 2015. "Comprehensive Study of the Human Rights Situation of Roma Worldwide, With a Particular Focus on the Phenomenon of Anti-Gypsyism", Report to the Human Rights Council, June

Kabachnik, P. 2010. "Place Invaders: Constructing the Nomadic Threat in England." Geographical Review 100 (1): 90-108.

Keresztely, K., J. W. Scott, and T. Virag. 2017. "Roma Communities, Urban Development and Social Bordering in the Inner City of Budapest." Ethnic and Racial Studies 40 (7). doi:10.1080/01419870.2017.1267376.

Klímová-Alexander, I. 2007. "Transnational Romani and Indigenous Non-territorial Selfdetermination Claims." Ethnopolitics 6 (3): 395-416. 
Ladányi, J., and I. Szelényi. 2006. Patterns of Exclusion: Constructing Gypsy Ethnicity and the Making of an Underclass in Transitional Societies of Europe. New York, NY: Columbia University Press.

Matras, Y. 2002. Romani: A Linguistic Introduction. Cambridge: Cambridge University Press.

McCall, L. 2005. "The Complexity of Intersectionality." Signs: Journal of Women in Culture and Society 30 (3): 1771-1800.

McGarry, A. 2012. "The Dilemma of the European Union's Roma Policy." Critical Social Policy 32 (1): 126-136.

McVeigh, R. 1997. "Theorising Sedentarism: the Roots of Anti-nomadism." In Gypsy Politics and Traveller Identity, edited by T. Acton, 7-25. Hatfield: University of Hertfordshire Press.

Newman, D. 2006. "Borders and Bordering towards an Interdisciplinary Dialogue." European Journal of Social Theory 9 (2): 171-186.

Nirenberg, J. 2010. "Romani Political Mobilisation from the First International Romani Union Congress to the European Roma, Sinti and Travellers Forum." In Romani Politics in Contemporary Europe, edited by N. Sigona and N. Trehan, 94-115. New York: Palgrave Macmillan.

Orta, L. 2010. Mapping the Invisible: EU-Roma Gypsies. London: Black Dog.

Pusca, A. 2010. "The 'Roma Problem' in the EU: Nomadism, (In)Visible Architectures and Violence." Borderlands 9 (2): 1-17.

Puxon, G. 2000. "The Romani Movement: Rebirth and the First World Romani Congress in Retrospect." In Scholarship and the Gypsy Struggle, edited by T. Action, 94-113. Hertfordshire: University of Hertfordshire Press.

Rattansi, A. 2007. Racism: A Very Short Introduction. Oxford: Oxford University Press.

Ruzicka, M. 2012. "Continuity or Rupture? Roma/Gypsy Communities in Rural and Urban Environments under Post-socialism." Journal of Rural Studies 28 (2): 81-88.

Sokol, M. 2001. "Central and Eastern Europe a Decade after the Fall of State-socialism: Regional Dimensions of Transition Processes." Regional Studies 35 (7): 645-655.

Solomos, J., and L. Back. 1996. Racism and Society. London: Macmillan.

Taylor, C. 1994. Multiculturalism. Edited by A. Gutman. Princeton, NJ: Princeton University Press.

Varjú, V. and S. Plaut. 2017. "Media mirrors? Framing Hungarian Romani Migration to Canada in Hungarian and Canadian Press." Ethnic and Racial Studies 40 (7). doi:10. 1080/01419870.2017.1266007.

Vermeersch, P. 2012. "Reframing the Roma: EU Initiatives and the Politics of Reinterpretation." Journal of Ethnic and Migration Studies 38 (8): 1195-1212.

Wemyss, G., and K. Cassidy. 2017. "'People Think that Romanians and Roma are the Same': Everyday Bordering and the Lifting of Transitional Controls." Ethnic and Racial Studies 40 (7). doi:10.1080/01419870.2017.1267381.

Yuval-Davis, N. 2006. "Intersectionality and Feminist Politics." European Journal of Women's Studies 13 (3): 193-209.

Yuval-Davis, N. 2011. The Politics of Belonging: Intersectional Contestations. London: Sage.

Yuval-Davis, N. 2014. "Situated Intersectionality and Social Inequality." Raisons Politiques 58: 91-100.

Yuval-Davis. N., V. Varjú, M. Tervonen, J. Hakim, and M. Fathi. 2017. “Press Discourses on Roma in the UK, Finland and Hungary." Ethnic and Racial Studies 40 (7). doi:10.1080/ 01419870.2017.1267379.

Yuval-Davis, N., G. Wemyss, and K. Cassidy. 2017. Bordering. Cambridge: Polity Press. 